\title{
Micropropagation of Anthurium spp.
}

\author{
Çimen Atak and Özge Çelik
}

Additional information is available at the end of the chapter

http://dx.doi.org/10.5772/51426

\section{Introduction}

Micropropagation as an alternative method to conventional propagation, the culture of somatic cells, tissues and organs of plants under controlled conditions is a suitable way to produce a large number of progeny plants which are genetically identical to the stock plant in a short time. The important property of the plant cells is totipotency which is a capacity to produce the whole plant from different plant parts. Micropropagation has some features to be chosen in commercial production such as multiplicative capacity in a relatively short time, healthy and disease-free production capacity and ability to generate population during a year [1-5].

The genetic pattern of the plant is key element to select the propagation method. Using micropropagation techniques in plant biotechnology applications are costlier than conventional propagation methods. Propagation by using in vitro techniques instead of conventional methods offer some advantages like utilizing small pieces of plants called as explants to maintain the whole plant and increase their number. The main point is to evolve new strategies to lower the time and cost consumed per plant [2,3]. In tissue culture applications selection of initiating material is important in the beginning of the culture. Therefore it is easy to provide virus-free clones in a short time. Production of plants during all year long independent of seasonal changes, long storage periods make micropropagation preferable to propagate plants in short time. There are also some disadvantages of micropropagation. Adaptation of cultured plants to the environmental conditions need transitional period to allow the plants to produce organic matter by photosynthesis $[2,4]$.

The main methods of in vitro propagation can be classified in two groups:

1. Propagation from axillary or terminal buds

2. Propagation by the formation of adventitious shoots or adventitious somatic embryos

The meristem and shoot tip cultures are used to establish virus-free plant culture. Many important horticulture crops were propagated by meristem culture for rapid growth and 
virus elimination. Adventitious shoots or adventitious somatic embryos are established directly or indirectly. Cultures are directly started with the excised explants from the mother plant tissues for organogenesis or embryogenesis. If shoots or embryos regenerate on previously formed callus or in cell culture, they are called as indirect organogenesis or embryogenesis $[3,6,7]$.

When propagation occurs via an indirect callus phase, the genetic identity of the progenies decreases. This is an important problem in commercial propagation to affect the uniformity of progenies. Callus formation also increases the somaclonal variation. Increasing of somaclonal variation incidence is a crucial result of long term period of callus growth. Origin of the callus also causes somaclonal variation.

Propagation from axillary or terminal buds is the most ensurable method to have the highest genetic stability during in vitro propagation of plants.

George et al. [2008] described five stages of micropopagation which are mother plant selection and preparation [Stage 0], in vitro culture establishment [Stage 1], shoot multiplication [Stage 2], rooting of microshoots [Stage 3] and acclimatization [Stage 4]. These stages are necessary for a successful micropropagation.

Establishing aseptic culture conditions can be classified as Stage 0 which contains presurface sterilization applications of explants to reduce contamination of stock plants. The success of Stage 2 depends on different factors such as plant species, cultivar or genotype, plant growth regulators, the ingredients of the medium and physical culture conditions. Stage 3 is responsible of rooting of microshoots. It depends on the factors given in Stage 2. Transplantation of rooted shoots to the environment is the main step of Stage 4 . This is also the important part of micropropagation. Acclimatization needs to be well controlled to avoid loss of propagated plants [4,5].

\section{Propagation of Anthurium}

The commercial production of ornamental pot plants has a great potential in international markets. In the global market, Anthurium cultivars with valued flowers are the second beside the Orchids among tropical cut flowers. Anthurium species and hybrids in Araceae family have an importance in monocotyledonous ornamental plants and they are commercially produced as cut flowers and potted plants in tropical and subtropical countries $[2,8-12]$.

The propagation rate of Anthurium by seeds is very low and it is not recommended. The cultivation has also been limited because of the inherent heterozygosity. The time between pollination and seed maturity and the development time take three years in a breeding program. To grow plants from seed may not provide a practical method of making new planting areas, in such circumstances vegetative propagation [stem cutting] seems the only way of multiplying a unique individual. Propagation method selection for a plant depends on its genetic potential and its intended use. Stem cutting methods are also not practical to propagate in large scale. Today Anthurium can be multiplied in large number by 
micropropagation. Application of biotechnology on in vitro propagation of Anthurium is important to increase the productivity of Anthurium [3, 6, 13].

\subsection{Tissue culture of Anthurium}

In vitro propagation methods have several advantages over conventional propagation like flexible adjustment of factors affecting regeneration such as explant type, nutrient and plant growth regulator levels and conditions of the environment, production of clones in desired rate, continued production during seasonal changes using tissue culture methods also increase the multiplication rate of plants [14].

\section{Explant type}

The success of tissue culture is related to the correct choice of explants. Shoot or shoot tips and node cultures are the most commonly used culture types in micropropagation of plants. Explants from shoot tips and nodal stem segments are suitable for enhanced axillary branching. Anthurium micropropagation from axillary buds, shoot tip, lamina explants, node, petiole, and microcuttings have been successfully utilized [15-18]. Among these plant parts, leaves are the most used explant source in in vitro culture of Anthurium.

The genotype of Anthurium plays an important role in in vitro propagation. The studies showed that different genotypes had different responses to the same culture conditions. For this reason, it is necessary to establish a suitable procedure for each varieties of Anthurium that can be adapted to commercial production $[3,4,19,20]$.

Selection of explant type to induce callogenesis and orgonogenesis is important for plants. In direct and indirect orgonogenesis studies, using young leaf explants are important for the success of culture. Martin et al.[2003] observed higher number of shoots in the brown young lamina explants than young green lamina. Viégas et al.[2007] also indicated the importance of using new brown leaves for callus induction. Bejoy et al.[2008] reported that the explants excised from pale green leaves showed better callus development than pale brown leaves. Atak and Çelik [2009] also used young brown and green leaves of Anthurium andreanum to evaluate the effectiveness of callus formations. They achieved to decrease the callus formation time by using brown leaf explants and induced the callus formation percentage $50 \%$ more than performed by green leaves.

\section{Establishing aseptic culture}

The second important step in micropropagation is to obtain aseptic culture of plant material. Aseptic culture systems are effective to eradicate the bacterial, fungal and insect contaminants. The sterilization protocols used for different Anthurium explant sources were given in Table $1 . \mathrm{NaOCl}$ is the main disinfection material used in establishing aseptic culture conditions of Anthurium. $\mathrm{NaOCl}$ has been used for the concentrations differ from $1 \%-5 \%$ [Table 1]. The incubation times of the explants in sodium hypochloride showed differences due to its concentrations. There is also need to used extra disinfectant solutions to eradicate the fungal and bacterial contaminants. Benomyl [commercial name 
is Benlate], Cetrimite, gentamicin and streptomycin sulphate are effectively used for this aim $[11,13,15,18,20,22]$.

\begin{tabular}{|c|c|c|c|}
\hline A. species & Explant Source & Sterilization method & Reference \\
\hline \multirow[t]{3}{*}{ A.andreanum } & Leaf & $\begin{array}{l}0.6 \% \text { Benlate }[30 \mathrm{~min}]+70 \% \text { ethanol } \\
{[30 \mathrm{sec}]+1.5 \% \mathrm{NaOCl} \text { containing }} \\
\text { two drops of Tween } 20 \text { [20 min] }\end{array}$ & {$[15]$} \\
\hline & Leaf & $0.1 \% \mathrm{HgCl}_{2}$ & [19] \\
\hline & Leaf & $\begin{array}{l}70 \% \text { ethanol }[1 \mathrm{~min}]+\text { gentamicin } \\
{[30 \mathrm{~min}]+20 \%[\mathrm{v} / \mathrm{v}] \text { commersial }} \\
\text { bleach }[5 \% \mathrm{NaOCl}, 12 \mathrm{~min}]\end{array}$ & [20] \\
\hline \multirow[t]{3}{*}{ A.andreanum L. } & $\begin{array}{l}\text { Apical shoot } \\
\text { buds }\end{array}$ & $\begin{array}{l}\text { Teepol+ antifungal solution } \\
\text { Cetrimite }[5 \mathrm{~min} .]+\mathrm{NaOCl}[5 \mathrm{~min}]+ \\
0.1 \%[\mathrm{w} / \mathrm{v}] \mathrm{HgCl}_{2}[5 \mathrm{~min} .]\end{array}$ & {$[11]$} \\
\hline & Spadices & $\begin{array}{l}\text { Washing under running tap water } \\
\text { [ } 30-60 \mathrm{~min}]+1 \% \text { pesticide solution } \\
\text { of } 50 \% \text { benomyl and } 20 \% \\
\text { streptomycin sulphate }[30 \mathrm{~min}]+5 \\
\text { times distilled water [ } 5 \mathrm{~min} \text { each } \\
\text { rinse.]+ } \\
1 \% \mathrm{NaOCl}[10 \mathrm{~min}]+2 \% \mathrm{NaOCl} \\
{[5 \mathrm{~min}]+80 \% \text { alcohol }[30 \mathrm{~s} .]+5-6} \\
\text { times distilled water [ } 5 \mathrm{~min} \text { each } \\
\text { rinse.] }\end{array}$ & [22] \\
\hline & $\begin{array}{l}\text { Leaf and } \\
\text { spadix } \\
\text { Segments }\end{array}$ & $\begin{array}{l}\text { Washing under running tap water } \\
{[30 \mathrm{~min}]+0.5 \% \text { [v/v]Trix }} \\
\text { [Commercial detergent }]+70 \% \\
\text { ethanol }[1 \mathrm{~min} .]+1.5 \% \mathrm{NaOCl} \\
\text { containing } 0.01 \% \text { Tween } 20 \text { [ } 8 \mathrm{~min}]\end{array}$ & [23] \\
\hline \multirow[t]{2}{*}{$\begin{array}{l}\text { A.andreanum } \\
\text { cv Rubrun }\end{array}$} & $\begin{array}{l}\text { Seeds from } \\
\text { plant spadix }\end{array}$ & $1 \% \mathrm{NaOCl}[20 \mathrm{~min}]$ & [7] \\
\hline & $\begin{array}{l}\text { Separate fruits } \\
\text { from spadix } \\
\text { Isolate seeds }\end{array}$ & $\begin{array}{l}3 \%[\mathrm{v} / \mathrm{v}] \mathrm{NaOCl}[15 \mathrm{~min}]+3 \text { times } \\
\text { distilled water }[5 \mathrm{~min} .] \\
1 \%[\mathrm{v} / \mathrm{v}] \mathrm{NaOCl}[20 \mathrm{~min}]+2 \text { times } \\
\text { distilled water [10min.] }\end{array}$ & [18] \\
\hline \multirow[t]{2}{*}{ A.andreanum Hort } & $\begin{array}{l}\text { Lamina } \\
\text { segments }\end{array}$ & $\begin{array}{l}5 \%[\mathrm{v} / \mathrm{v}] \text { Extran }[5 \mathrm{~min} \text {. with } \\
\text { detergent] }+0.1 \%[\mathrm{w} / \mathrm{v}] \text { mercuric } \\
\text { chloride }[10-12 \mathrm{~min}]\end{array}$ & [1] \\
\hline & Leaf & $\begin{array}{l}15 \%[\mathrm{v} / \mathrm{v}] \text { commersial bleach }[20 \\
\mathrm{min}]+0.1 \% \mathrm{HgCl}_{2}[7 \mathrm{~min}]\end{array}$ & [21] \\
\hline
\end{tabular}

Table 1. Sterilization methods used in Anthurium tissue culture 


\section{Culture medium}

Culture medium influences the propagation efficiency in plant tissue culture applications. Organic compounds, vitamins and plant growth regulators are used to stimulate healthy growth. The rate of tissue growth and morphogenetic responses highly affected by the features of nutrients included.

There are several basal media such as Chu [N6] [24], Gamborg's B5 [25], Murashige and Skoog [MS] [26], Murashige and Tucker [MT] [27] and Nitsch and Nitsch [NN] [28]. These media are successfully used for establishing tissue cultures of different explants of various plants [22].

In plant tissue culture studies, different combinations of every medium based on different concentrations of macro and micronutrients have been used to develop efficient protocols. The rapid and efficient tissue culture protocols are important for micropropagation of Anthurium as much as in other plants.

The success of plant tissue culture depends on the composition of the medium used. Different combinations of macronutrients as nitrogen, potassium, calcium, phosphorus, magnesium and sulphur and micronutrients [trace elements] as iron, nickel, chlorine, manganase, zinc, boron, copper and molybdenum change the nature of the medium.

Each plant species has its own medium composition or it should be improved for better results. The modifications can be made up in macro and micronutrients, sugar content, plant growth regulators, vitamins and other nitrogen supplements.

MS media with some modifications have been frequently applied in tissue culture of Anthurium. The differences caused by using different concentrations of plant growth regulators in combination with MS organics used to obtain desired tissues [Table 2].

Nitrogen is an essential macronutrient in plant life. It is an important component of proteins and nucleic acids. Nitrate $\left[\mathrm{NO}_{3}^{-}\right]$is the main source of nitrogen. $\mathrm{NO}_{3}^{-}$is reduced to ammonium $\left[\mathrm{NH}_{4}^{+}\right]$after uptake. Plants have ability to use the reduced form of nitrogen for their metabolism. Nitrate uptake happens effectively in an acidic $\mathrm{pH}$. But after nitrate uptake, the medium are becoming less acid. When ammonium uptake, it makes the medium more acidic. The $\mathrm{pH}$ of the plant culture media is important because in a buffered media, existence of both ions affects efficient nitrogen uptake. The form and the amount of nitrogen in media have significant effects on cell growth and differentiation. $\mathrm{pH}$ controlling in the media is not the only reason of using both ions, excessive ammonium ions are toxic to the plants. Media containing high levels of $\mathrm{NH}_{4}{ }^{+}$also inhibits chlorophyll synthesis [4].

It has been known that the root growth is induced by $\mathrm{NO}_{3}{ }^{-}$and reduced by $\mathrm{NH}_{4}^{+}$. But morphogenesis is being controlled by total amount of nitrogen in the medium and it needs both of $\mathrm{NO}_{3}^{-}$and $\mathrm{NH}_{4}^{+}$. Because of using optimum $\mathrm{NH}_{4}^{+}$: $\mathrm{NO}_{3}^{-}$has a key role in morphogenesis, therefore the balance between $\mathrm{NO}_{3}{ }^{-}$and $\mathrm{NH}_{4}{ }^{+}$differs for different plants and different kinds of cultures. This situation implies that this ratio should be specifically adjusted for each plant species and for different purposes. Changing the $\mathrm{NO}_{3}{ }^{-}$to $\mathrm{NH}_{4}{ }^{+}$ratio by small alterations affects differentiation and growth. 


\begin{tabular}{|c|c|c|c|c|}
\hline $\begin{array}{c}\text { Anthurium } \\
\text { species }\end{array}$ & $\begin{array}{l}\text { Explant } \\
\text { source }\end{array}$ & Medium components & Aim & Reference \\
\hline \multirow[t]{14}{*}{ A.andreanum } & Leaf & $\mathrm{MS}+2.2-4.4 \mu \mathrm{M} \mathrm{BA}+0.9 \mu \mathrm{M} 2,4-\mathrm{D}$ & $\begin{array}{l}\text { Adventitious } \\
\text { shoots }\end{array}$ & {$[33]$} \\
\hline & Root & Modified MS+2.2 $\mu \mathrm{MBA}$ & Multiple shoots & {$[34]$} \\
\hline & \multirow[t]{3}{*}{ Leaf } & $\begin{array}{l}\text { Modified Nitsch [200mg/l } \\
\left.\mathrm{NH}_{4} \mathrm{NO}_{3}\right]+1 \mathrm{mg} / 1 \mathrm{BA}+0.1 \mathrm{mg} / 1 \\
\text { 2,4-D }\end{array}$ & $\begin{array}{l}\text { Callus } \\
\text { initiation }\end{array}$ & \multirow[t]{3}{*}{ [15] } \\
\hline & & $\begin{array}{l}\text { Nitsch }\left[720 \mathrm{mg} / 1 \mathrm{NH}_{4} \mathrm{NO}_{3}\right] \\
+0.5 \mathrm{mg} / \mathrm{l} \mathrm{BA}\end{array}$ & $\begin{array}{l}\text { Shoot } \\
\text { development }\end{array}$ & \\
\hline & & $\begin{array}{l}\text { Nitsch }\left[720 \mathrm{mg} / 1 \mathrm{NH}_{4} \mathrm{NO}_{3}\right] \\
+1.0 \mathrm{mg} / \mathrm{l} \mathrm{IBA}+0.04 \% \mathrm{AC}\end{array}$ & Roots & \\
\hline & \multirow[t]{3}{*}{ Leaf } & $1 / 2 \mathrm{MS}+0.6 \mathrm{mg} / 1$ 2,4-D+1mg/l BAP & $\begin{array}{l}\text { Callus } \\
\text { induction }\end{array}$ & \multirow[t]{3}{*}[20]{} \\
\hline & & $\begin{array}{l}1 / 2 \mathrm{MS}+250 \mathrm{mg} / 1 \mathrm{NH}_{4} \mathrm{NO}_{3}+0.1 \mathrm{mg} / 1 \\
2,4-\mathrm{D}+1 \mathrm{mg} / 1 \mathrm{BA}\end{array}$ & $\begin{array}{l}\text { Shoot } \\
\text { regeneration }\end{array}$ & \\
\hline & & $1 / 2 \mathrm{MS}+1 \mathrm{mg} / 1 \mathrm{IBA}+0.04 \% \mathrm{AC}$ & Roots & \\
\hline & \multirow[t]{2}{*}{ Leaf, spadix } & $1 / 4 \mathrm{MS}+1 \mathrm{mg} / \mathrm{l} \mathrm{BAP}$ & Multiple shoots & \multirow[t]{2}{*}[23]{} \\
\hline & & 1/4MS+1mg/l IBA & Roots & \\
\hline & Seed & $\mathrm{MS}+2 \mathrm{mg} / \mathrm{l} \mathrm{BA}+0.5 \mathrm{mg} / \mathrm{l} \mathrm{NAA}$ & $\begin{array}{l}\text { Callus } \\
\text { proliferation }\end{array}$ & [18] \\
\hline & \multirow[t]{3}{*}{ Petiol } & $1 / 2 \mathrm{MS}+0.1 \mathrm{mg} / 12,4-\mathrm{D}+0.5 \mathrm{mg} / \mathrm{lBA}$ & Callus & \multirow[t]{3}{*}[36]{} \\
\hline & & $1 / 2 \mathrm{MS}+0.1 \mathrm{mg} / 12,4-\mathrm{D}+1.0 \mathrm{mg} / \mathrm{l} \mathrm{BA}$ & Shoot & \\
\hline & & $1 / 2 \mathrm{MS}+0.5 \mathrm{mg} / 12,4-\mathrm{D}$ & Root & \\
\hline \multirow[t]{4}{*}{ Anthurium ssp. } & \multirow[t]{4}{*}{ Leaf } & $1 / 2 \mathrm{MS}+1 \mathrm{mg} / 1 \mathrm{BA}+0.08 \mathrm{mg} / 12,4-\mathrm{D}$ & $\begin{array}{l}\text { Callus } \\
\text { induction }\end{array}$ & \multirow[t]{4}{*}[19]{} \\
\hline & & $1 / 2 \mathrm{MS}+1 \mathrm{mg} / \mathrm{l} \mathrm{BA}$ & $\begin{array}{l}\text { Callus } \\
\text { multiplication }\end{array}$ & \\
\hline & & $\begin{array}{l}\left.\text { 1/2MS[206 mg/l NH}{ }_{4} \mathrm{NO}_{3}\right]+1 \mathrm{mg} / \mathrm{l} \\
\mathrm{BA}\end{array}$ & $\begin{array}{l}\text { Shoot } \\
\text { regeneration }\end{array}$ & \\
\hline & & $1 / 4 \mathrm{MS}+1 \mathrm{~g} / \mathrm{l} \mathrm{AC}$ & Roots & \\
\hline $\begin{array}{l}\text { A.andreanum } \\
\text { André cv. }\end{array}$ & Leaf, petiole & $\begin{array}{l}\text { Modified Pietrik } \\
\text { medium }+0.36 \mu \mathrm{M} 2,4-\mathrm{D}+4.4 \mu \mathrm{M} \\
\text { BA }\end{array}$ & Callus & {$[32]$} \\
\hline $\begin{array}{l}\text { Anthurium } \\
\text { andreaum } \mathrm{cv} \\
\text { Rubun }\end{array}$ & $\begin{array}{l}\text { Microcutting } \\
\text { from } \\
\text { germinated } \\
\text { seed }\end{array}$ & $\mathrm{MS}+4.4 \mu \mathrm{M}$ BA $+0.05 \mu \mathrm{M}$ NAA & Multiple shoots & [7] \\
\hline \multirow[t]{2}{*}{$\begin{array}{l}\text { A.andreanum } \\
\text { Lind. }\end{array}$} & \multirow[t]{2}{*}{$\begin{array}{l}\text { Apical shoot } \\
\text { bud }\end{array}$} & $\mathrm{MS}+0.1 \mathrm{mg} / 1 \mathrm{NAA}+0.25 \mathrm{mg} / \mathrm{BAP}$ & $\begin{array}{l}\text { Multiple apical } \\
\text { shoots }\end{array}$ & \multirow[t]{2}{*}[11]{} \\
\hline & & $\begin{array}{l}\mathrm{MS}+0.5 \mathrm{mg} / \mathrm{B} \mathrm{BAP}+60 \mathrm{mg} / \mathrm{l} \\
\text { adenine sulphate }\end{array}$ & Multiple shoots & \\
\hline
\end{tabular}




\begin{tabular}{|c|c|c|c|c|}
\hline $\begin{array}{l}\text { Anthurium } \\
\text { species }\end{array}$ & $\begin{array}{l}\text { Explant } \\
\text { source }\end{array}$ & Medium components & Aim & Reference \\
\hline & & $\mathrm{MS}+0.5 \mathrm{mg} / \mathrm{l} \mathrm{IAA}+2 \mathrm{~g} / \mathrm{l} \mathrm{AC}$ & Roots & \\
\hline & $\begin{array}{l}\text { Half anther } \\
\text { culture }\end{array}$ & $\begin{array}{l}\mathrm{NWT}+0.25 \mathrm{mg} / \mathrm{l} 2,4-\mathrm{D}+0.02 \mathrm{mg} / \mathrm{l} \\
\mathrm{NAA}+1.5 \mathrm{mg} / \mathrm{l} \mathrm{TDZ}+0.75 \mathrm{mg} / \mathrm{l} \\
\mathrm{BAP}\end{array}$ & $\begin{array}{l}\text { Callus } \\
\text { Shoot } \\
\text { regeneration }\end{array}$ & [22] \\
\hline & & $\begin{array}{l}\mathrm{NWT}+0.2 \mathrm{mg} / \mathrm{l} \mathrm{NAA}+1.0 \\
\mathrm{mg} / \mathrm{lKIN}\end{array}$ & Roots & \\
\hline $\begin{array}{l}\text { A.andreanum } \\
\text { Lindl.cv. }\end{array}$ & $\begin{array}{l}\text { Nodal } \\
\text { segments }\end{array}$ & $\mathrm{MS}+4.44 \mathrm{mM} \mathrm{BAP}+2.89 \mathrm{mM} \mathrm{GA}_{3}$ & Shoot induction & [16] \\
\hline \multirow[t]{10}{*}{$\begin{array}{l}\text { A.andreanum } \\
\text { Hort }\end{array}$} & Lamina & $\begin{array}{l}1 / 2 \mathrm{MS}+1.11 \mu \mathrm{M}+\mathrm{BA}+1.14 \mu \mathrm{M} \\
\mathrm{IAA}+0.46 \mu \mathrm{M} \text { Kin }\end{array}$ & Shoot induction & {$[1]$} \\
\hline & & $1 / 2 \mathrm{MS}+0.44 \mu \mathrm{M}$ BA & Multiple shoots & \\
\hline & & $\begin{array}{l}\frac{1}{2} \mathrm{MS}+0.54 \mu \mathrm{M}+\mathrm{NAA}+0.93 \mu \mathrm{M} \\
\text { Kin }\end{array}$ & Roots & \\
\hline & Leaf & $\begin{array}{l}1 / 4 \mathrm{MS}+0.88 \mu \mathrm{M} \text { BA+ }+0.9 \mu \mathrm{M} 2,4- \\
\mathrm{D}+0.46 \mu \mathrm{M} \text { Kin }\end{array}$ & Callus & [35] \\
\hline & & $\begin{array}{l}1 / 4 \mathrm{MS}+0.88 \mu \mathrm{M} \text { BA }+0.54 \mu \mathrm{M} \\
\mathrm{NAA}+0.46 \mu \mathrm{M} \text { Kin }\end{array}$ & Multiple shoots & \\
\hline & & $1 / 2 \mathrm{MS}+0.54 \mu \mathrm{M}$ NAA & Roots & \\
\hline & & $1 / 2 \mathrm{MS}+0.5 \mathrm{mg} / 1$ 2,4-D+1mg/1 BAP & $\begin{array}{l}\text { Adventitious } \\
\text { shoots }\end{array}$ & [21] \\
\hline & Leaf, petiole & $1 / 2 \mathrm{MS}+0.90 \mu \mathrm{M} 2,4-\mathrm{D}+8.88 \mu \mathrm{M}$ BA & $\begin{array}{l}\text { Callus } \\
\text { induction }\end{array}$ & [17] \\
\hline & & $1 / 2 \mathrm{MS}+0.90 \mu \mathrm{M} 2,4-\mathrm{D}+4.44 \mu \mathrm{M}$ BA & $\begin{array}{l}\text { Callus } \\
\text { proliferation }\end{array}$ & \\
\hline & & $\mathrm{MS}+5.71 \mathrm{mM}$ NAA & Roots & \\
\hline \multirow[t]{2}{*}{ A.scherzerianum } & Leaf & $\begin{array}{l}\text { 1/2MS+0.08mg/l 2,4-D+1mg/l } \\
\mathrm{BAP}+1 \mathrm{mg} / 12-\mathrm{iP}\end{array}$ & Callus & [10] \\
\hline & & $\mathrm{MS}+0.5 \mathrm{mg} / \mathrm{l} \mathrm{BAP}$ & Shoots & \\
\hline $\begin{array}{l}\text { A.scherzerianum } \\
\text { Schott }\end{array}$ & Leaf & $\begin{array}{l}\text { Modified MS+2.5 mM } \\
\mathrm{NH}_{4} \mathrm{NO}_{3}+18 \mu \mathrm{M} 2,4-\mathrm{D}+6 \% \\
\text { sucrose }\end{array}$ & $\begin{array}{l}\text { Embryo } \\
\text { induction }\end{array}$ & [6] \\
\hline
\end{tabular}

BAP, 6-benzylaminopurine; BA, N6-benzyladenine; 2,4-D, 2,4-dichlorophenoxyacetic acid, IAA, indole-3-acetic acid; IBA, indole-3-butyric acid; 2-iP, N6-[2-isopentenyl]adenine; Kin, kinetin; NAA, $\alpha$-naphthalene acetic acid; TDZ, thidiazuron; AC, activated charcoal; AS, adenin sulphate; MS, Murashige Skoog [1962] medium; WM: WinartoTeixeria medium, NWM: New Winarto-Teixeria medium GA3, giberellic acid.

Table 2. In vitro culture medium components for Anthurium cultivars (Modified from [22]).

MS media used frequently for tissue culture of Anthurium and the ratio of $\mathrm{NO}_{3}^{-}$to $\mathrm{NH}_{4}{ }^{+}$is 66:34 at this medium. For this reason generally modified MS medium used at Anthurium organogenesis. The modifications of ammonium nitrate concentration have been studied at Anthurium media by researchers. Hamidah et al. [1997] used half-strength MS 
macroelements with $2.5 \mathrm{mM}$ ammonium nitrate for in vitro stock cultures. While Puchooa [2005] used $200 \mathrm{mg} / \mathrm{L}$ reduced ammonium nitrate concentration for callus culture, they increased the amount to $720 \mathrm{mg} / \mathrm{L}$ for regeneration. Dufour and Guérin [2005] used different compositions of $\mathrm{NO}_{3}$ and $\mathrm{NH}_{4}$ to evaluate the developmental results. According to their results, the ratio of 0.37 showed better plant growth and development. Atak and Çelik [2009] preferred to use half-strength MS salts with $\mathrm{NH}_{4} \mathrm{NO}_{3}$ lowered to $250 \mathrm{mg} / \mathrm{L}$ for shoot regeneration. Winarto et al. [2011] were improved a protocol for callus induction and plant regeneration and NWT-3 media contains $750 \mathrm{mg} / 1 \mathrm{NH} \mathrm{NNO}_{3}$.

In culture conditions, using synthetic chemicals with similar physiological activities as plant hormones have capabilities to induce plant growth as desired. Auxin and cytokinins are the most important hormones regulating growth and morphogenesis in plant tissue culture. Their combinative usage promote growth of calli, cell suspensions, root and shoot development and have capability to regulate the morphogenesis [4,29]. There are synthetic auxin and cytokinins beside naturals. Different combinations and concentrations of plant growth regulators such as 2,4-dichlorophenoxyacetic acid [2,4-D], naphthalene acetic acid [NAA], benzylaminopurine [BAP] and kinetin [Kin] were used to indicate callus formation from different kinds of explants of Anthurium cultivars. In preliminary studies, induction and regeneration of callus followed by shoot and root regeneration are the main steps of tissue culture of whole plants. As an important commercial plant, to develop a rapid and more effective tissue culture protocol to shorten the time is the main objective of Anthurium tissue culture $[7,10,22,23]$.

As given in Table 2, combination of 2,4-D and BA in culture media to induce callus initiation from leaf explants in different varieties of Anthurium is frequently used. Also, adding of $\mathrm{BAP}$ and 2-iP to the callus medium has been evaluated by different researchers. The concentrations of 2,4-D used in the callus medium is ranging from $0.08 \mathrm{mg} / 1$ to $1 \mathrm{mg} / 12,4-\mathrm{D}$. The BA concentrations are changing between $0.1 \mathrm{mg} / \mathrm{l}$ and $1 \mathrm{mg} / \mathrm{l}$.

Micropropagated plants require a developed root system to resist the external environmental conditions. Rooting of the shoots take place in vitro. Therefore, determination of the appropriate auxin type and levels in the media required to promote rooting [4].

Activated charcoal [AC] is added to medium for promoting root growth [11, 13, 15, 19, 20]. $\mathrm{AC}$ is composed of carbon and it is often used in plant tissue culture to absorb gases and dissolved solids. It is not a growth regulator but it has an ability to modify medium composition [4].

There are several advantageous uses of charcoal on the type of culture. These are adsorption of secreted compounds from cultured tissues, decrements in the phenolic oxidations, $\mathrm{pH}$ changes of the medium to optimize for morphogenesis, prevention of unwanted callus growth, simulation of soil conditions because of the ability to promote root formation, capability to use in production of secondary plant products in culture conditions $[4,30]$. 
The most important effect of using AC to the medium is the rigorous decrease in the concentrations of plant growth regulators and other organic supplements. AC shows greater adsorptive capacity to phenolics commonly produced by wounded tissues, plant hormones like IAA, NAA, IBA, BA, kinetin, zeatin and other hormones [30,31]. The adsorptive property of $\mathrm{AC}$ changes with purity, $\mathrm{pH}$ and density [3]. The Anthurium seedlings propagated by Atak and Çelik [2009] were rooted in medium containing AC and given in Figure 1.

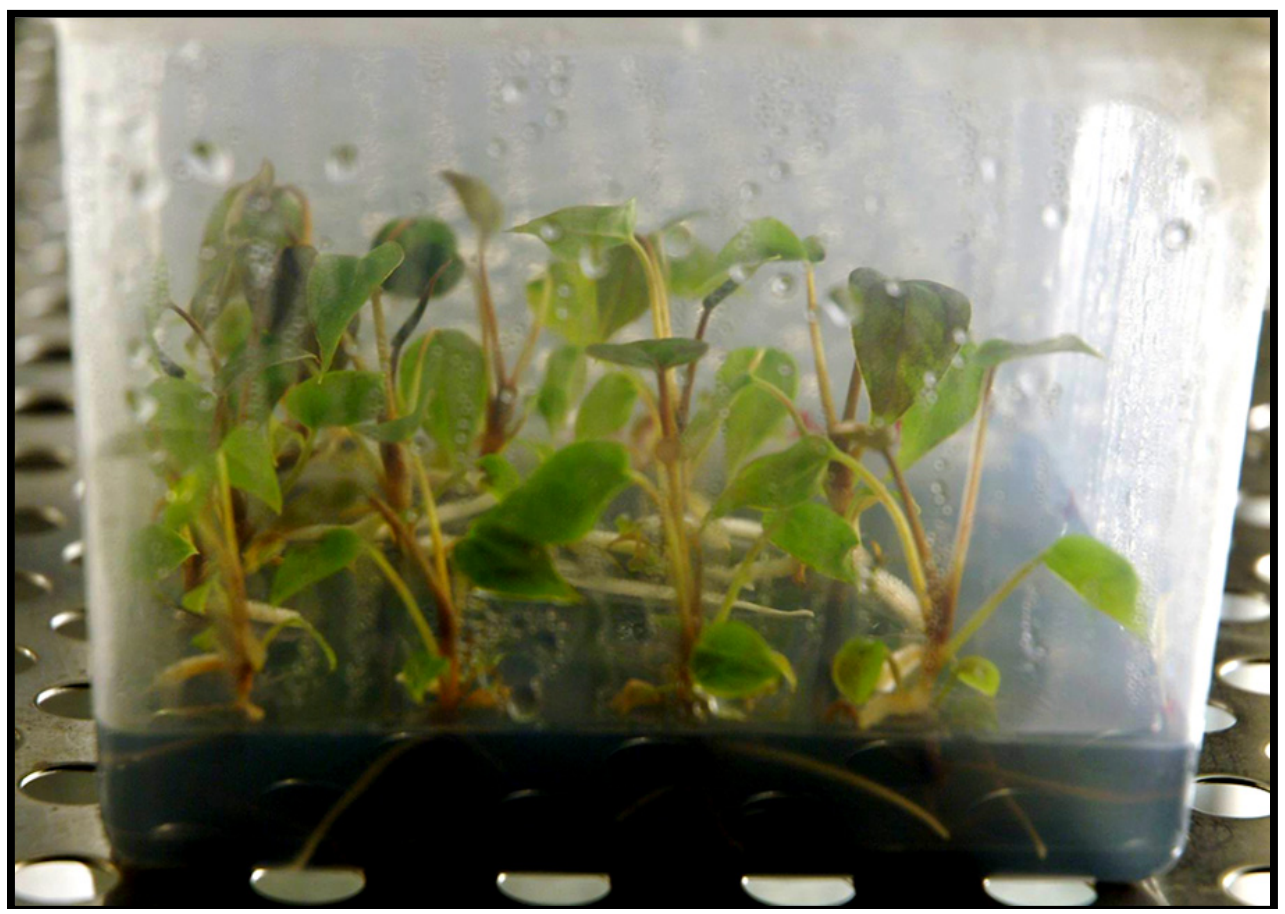

Figure 1. In vitro propagation of Anthurium cultivars [Arizona]. The shoots with root were growth inplant tissue culture medium with AC [20].

\section{The importance of subculturing in micropropagation}

In plant propagation applications, subculturing has an importance to prolong the life of plants and expand the number of cultured seedlings. At in vitro propagation of Anthurium andreanum cultivars, the number of shoots per explants was increased subsequent subcultures. Atak and Çelik [2009] observed that shoot multiplication for two Anthurium andreanum cultivars Arizona and Sumi was increased in the next multiplication stage. At every subculture, shoot numbers regenerated form nodal explants gradually increased [Table 3]. Bejoy et al.[2008] reported that multiplication was enhanced in the next multiplication stage. They succeeded to increase the rate of shoot production in the second multiplication stage. 


\begin{tabular}{|c|c|c|c|c|c|}
\hline Subculture & \multicolumn{2}{|c|}{ Arizona } & Subculture & \multicolumn{2}{|c|}{ Sumi } \\
\cline { 2 - 3 } & $\begin{array}{c}\text { Number of } \\
\text { Explants }\end{array}$ & $\begin{array}{c}\text { Number of } \\
\text { Shoots per } \\
\text { Explant } \\
{[\text { Mean } \pm \text { SE] }}\end{array}$ & & $\begin{array}{c}\text { Number of } \\
\text { Explants }\end{array}$ & $\begin{array}{c}\text { Number of Shoots } \\
\text { per Explant } \\
\text { [Mean } \pm \text { SE] }\end{array}$ \\
\hline Va1 & 50 & $15.64 \pm 1.69^{\mathrm{a}}$ & Vs1 & 50 & $12.24 \pm 1.18^{\mathrm{a}}$ \\
\hline Va2 & 50 & $22.70 \pm 1.46^{\mathrm{b}}$ & Vs $_{2}$ & 50 & $15.98 \pm 1.36^{\mathrm{b}}$ \\
\hline Va3 & 50 & $26.76 \pm 1.30^{\mathrm{c}}$ & Vs3 $_{3}$ & 50 & $21.82 \pm 1.87^{\mathrm{c}}$ \\
\hline Va4 & 50 & $33.70 \pm 1.09^{\mathrm{d}}$ & Vs $_{4}$ & 50 & $26.96 \pm 1.46^{\mathrm{d}}$ \\
\hline
\end{tabular}

Data presented as means with different letters within a column indicating significant differences at $\mathrm{P}<0.05$ according to Duncan's Multiple range test. Each mean represented 5 replications.

Abbreviations: $\mathbf{V a}$ = initial shoot [Shoot regeneration from callus cultures of Arizona variety] $\mathbf{V a}_{2}, \mathbf{V a}_{3}, \mathbf{V a}_{4}=$ subcultures of Arizona variety, Vss = initial shoot [Shoot regeneration from callus cultures of Sumi variety], Vs2, Vs s, $\mathrm{Vs}_{4}=$ subcultures of Sumi variety.

Table 3. Shoot multiplication of Anthurium andreanum cultivars [20].

\section{Acclimatization}

In micropropagation studies, the last and the critical step is acclimatization of the rooted seedlings to the environment. In this stage, plant losses have been due to different reasons $[37,38]$. Directly rooted shoots in soil show higher survival rate in the field than rooted under in vitro conditions. Therefore, there are several methods to high the survival rate of in vitro rooted shoots.

Cultured plants must adapt to low humidity, high light intensities and large temperature fluctuations with ex vitro acclimatization techniques. However these methods are expensive, time consuming and labor-intensive, in vitro acclimatization techniques have been improved. Using growth chambers which have relative humidity, controlled ventilation and possibility to change the components of the media make it possible to reduce the steps need for the process $[37,39]$.

The success of acclimatization of in vitro cultured plants depends on the nutrients reserved in the leaves during development [40]. The important point in acclimatization is to keep the rooted plants in incubator in order to keep the humidity high.

Different acclimatization protocols for in vitro regenerated A.andreanum plantlets have been reported. Soilrite-perlite with the rate of 10:1, vermicompost and sand mixture [1:3], vermiculite and perlite [1:1], soil and organic humus [1:1] are the most used acclimatization mediums with the high survival ratios ranging from $60 \%$ to $98 \%[1,10,13]$.

During in vitro development stage, the cultural conditions such as humidity, air turbulence, $\mathrm{CO}_{2}$ concentration, sugar content in medium effect acclimatization ability of plants to ex vivo conditions. Therefore, for each Anthurium varieties, efficient acclimatization protocols have to be improved to prolong the success of micropropagation. 


\section{Discussion and conclusion}

In micropropagation studies, the success of the protocols depends on the variety of Anthurium, explant type, the components of the media used for shoot and root regenerations. Different combinations of plant growth regulators and additives used in relation to increase the regeneration potential of the explants should be evaluated for each cultivars to determine the efficient tissue culture protocol. In this chapter, we compared the explant types and tissue culture components for Anthurium species which is an important ornamental pot plant.

Stages of the leaves show different response to propagation by indirect organogenesis. Explants prepared from brown leaves have higher callus formation rates in a shorter time than green leaf explants. Therefore, selection and using the right leaf explants at the appropriate leaf stage is the first step of establishing a successful tissue culture. Using different combinations of plant growth regulators and nitrogen additives should be evaluated to control the organogenesis for Anthurium varieties. $\mathrm{NO}_{3}{ }^{-}: \mathrm{NH}_{4}{ }^{+}$balance in the growth medium has to be adjusted for each Anthurium varieties to obtain desired differentiation and growth. Developing an ideal acclimatization condition is important to increase the survival rate of micropropagated and rooted seedlings to adapt to ex vivo conditions.

In conclusion, the primary point to be remembered is the effects of genotypical differences on culture efficiencies. Different genotypes of varieties show different organogenesis responses in explant cultures. Therefore for each Anthurium varieties suitable micropropagation methods should be determined.

\section{Author details}

Çimen Atak and Özge Çelik

Istanbul Kultur University, Faculty of Science and Letters,

Department of Molecular Biology and Genetics, Ataköy, Istanbul, Turkey

\section{References}

[1] Martin KP, Joseph D, Madassery J, Philip VJ. Direct shoot regeneration from lamina explants of two commercial cut flower cultivars of Anthurium andreanum Hort. In Vitro Cell. Dev. Biol-Plant 2003; 39 500-504.

[2] Rout GR, Mohapatra A, Jain SM. Tissue culture of ornamental pot plant: A critical review on present scenario and future prospects. Biotechnology Advances 2006; 24 531560.

[3] Harb EM, Talaat NB, Weheeda BM, El-Shamy M, Omira GA. Micropropagation of Anthurium andreanum from shoot tip explants. Journal of Applied Sciences Research 2010; 6(8) 927-931. 
[4] George EF, Hall MA, Klerk JD. Plant propagation by tissue culture, Volume 1. The 9Background, Springer, 2008.

[5] Dobranszki J, Silva JAT. Micropropagation of apple - A review. Biotechnology Advances 2010; 28 462-488.

[6] Hamidah M, Karim AGA, Debergh P. Somatic embryogenesis and plant regeneration in Anthurium scherzerianum. Plant Cell, Tissue and Organ Culture 1997; 48 189-193.

[7] Vargas TE, Mejias A, Oropeza M, Garcia E. Plant regeneration of Anthurium andreanum cv Rubrun. Electronic Journal of Biotechnology 2004;7(3) 285-289.

[8] Dufour L, Guerin V. Growth, developmental features and flower production of Anthurium andreanum Lind. in tropical condition. Scientia Horticulturae 2003; 98 25-35.

[9] Dufour L, Guerin V. Nutrient solution effects on the development and yield of Anthurium adreanum Lind. in tropical soilless conditions. Scientia Horticulturae 2005; 105 269-282.

[10] Viegas J, Rosa da Rocha MT, Ferreira-Moura I, Lairia da Rosa D, Almeida de Souza J, Correa MGS, Telxelra da Silva JA. Anthurium andraeanum [Linden ex Andre] culture: in vitro and ex vitro. Floricult. Ornamental Biotechnology 2007;1 61-65.

[11] Gantait S, Mandal N, Bhattacharyya S, Das PK. In vitro Mass Multiplication with pure genetic identity in Anthurium andreanum Lind. Plant Tissue Cult. Biotechnology 2008;18(2) 113-122.

[12] Gantait S, Sinniah UR. Morphology, flow cytometry and molecular assessment of exvitro grown micropropagated anthurium in comparison with seed germinated plants. African Journal of Biotechnology 2011;10(64) 13991-13998.

[13] Gantait S, Mandal N. Tissue culture of Anthurium andreanum: Asignificant review and future prospective. İnternational Journal of Botany 2010;6(3) 207-219.

[14] Silva JAT, Nagae S, Tanaka M. Effect of physical factors on micropropagation of Anthurium andreanum. Plant Tissue Culture 2005;15(1) 1-6.

[15] Puchooa D. In vitro mutation breeding of Anthurium by gamma radation. International Journal of Agricultural Biology 2005;7 11-20.

[16] Lima FC, Ulisses C, Camara TR, Cavalcante UMT, Albuquerque CC, Willadino L. Anthurium andraeanum Lindl. cv. Eidibel in vitro rooting and acclimation with arbuscular mycorrhizal fungi. Rev. Bras. Cienc. Arar. Recife 2006;1 13-16.

[17] Yu Y, Liu L, Liu J, Wang J. Plant regeneration by callus-mediated protocorm-like body induction of Anthurium andreanum. Hod. Agric Sci. China 2009; 8 572-577.

[18] Maira 0, Alexander M, Vargas TE. Micropropagation and organogenesis of Anthurium andraeanum Lind cv. Rubun. Jain SM, Ochatt SJ.[Eds.] Protocols for in vitro propagation of ornimental plants, Methods in Molecular Biology 2009;589 3-14.

[19] Nhut DT, Duy N, Vy NNH, Khue CD, Khiem DV, Vinh DN. Impact of Anthurium spp. genotype on callus induction derived from leaf explants and shoot and root regeneration capacity from callus. Journal of Applied Horticulture 2006;8(2) 135-137.

[20] Atak C, Celik O. Micropropagation of Anthurium andreanum from leaf explants. Pakistan Journal of Botany 2009;41 1155-1161. 
[21] Bejoy M, Sumitha VR, Anish NP. Foliar Regeneration in Anthurium andreanum Hort. cv. Agnihothri. Biotechnology 2008;7(1)134-138.

[22] Winarto B, Rachmawati F, Silva JAT. New basal media for half -anther culture of Anthurium andreanum Linden ex Andre cv. Tropical. Plant Growth Regulation 2011;65 513-529.

[23] Jahan MT, Islam MR, Khan R, Mamun ANK, Ahmed G, Hakim, L. In vitro clonal propagation of Anthurium [Anthurium andreanum L.] using callus culture. Plant Tissue Cult. Biotech. 2009;19 61-69.

[24] Chu CC, Wang CC, Sun CS, Hsu C, Yin KC, Chu CY, Bi FY. Establishment of an efficient medium for anther culture of rice through comparative experiments on the nitrogen sources. Science Sinica 1975;18 659-668.

[25] Gamborg O, Miller R, Ojimo K. Nutrient requirement suspensions cultures of soybean root cells. Experimental Cell Research 1968;50(1) 151-158.

[26] Murashige T, Skoog F. A revised medium fo rapid growth and bio-assays with tobacco tissue cultures. Physiologica Plantarum 1962;15 473-497.

[27] Murashige T, Tucker DPH. Growth factor requirements of Citrus tissue culture. Proc. $1^{\text {st }}$ In. Citrus Symp. 1969;3 1155-1161.

[28] Nitsch JP and Nitsch C. Haploids plants from Pgrains. Science 1969;163 85-87.

[29] Bajguz A, Piotrowska A. Conjugates of auxin and cytokinin. Phytochemistry 2009;70(8) 957-969.

[30] Thomas TD. The role of activated charcoal in plant tissue culture. Biotechnology Advences 2008;26 618-631.

[31] Asaduzzaman M, Asao T. Autotoxicity in beans and their allelochemicals. Scientia Horticulturae 2012;134(1) 26-31.

[32] Kuehnle AR, Sugii N. Callus induction and plantlet regeneration in tissue culture of Hawaiian Anthuriums. Hort Science 1991;26 919-921.

[33] Teng WL. Regeneration of Anthurium adventitious shoots using liquid or raft culture. Plant Cell,Tissue and Organ Culture 1997;49 153-158.

[34] Chen FC, Kuehnle A, Sugii N. Anthurium roots for micropropagation and Agrobacterium tumefaciens-mediated gene transfer. Plant Cell, Tissue and Organ Culture 1997;49 71-74.

[35] Joseph M, Martin KP, Mundassery J, Philip VJ. In vitro propagation of three commercial cut flower cultivars of Anthurium andreanum. Hortic. Indian Journal of Experimental Biology 2003;41 154-159.

[36] Zhao Q, Jing J, Wang G, Wang JH, Feng YY, Xing HW, Guan CF. Optimization in Agrobacterium-medium transformation of Anthurium andreanum using GFP as a reporter. Electronic Journal of Biotechnology 2010;13(5)1-11.

[37] Diaz LP, Namur JJ, Bollati SA, Arce OEA. Acclimatization of Phalaeropsis and Cattleya obtained by micropropagation. Rev. Colomb. Biotechnol. 2010;12(2) 27-40.

[38] Hazarika BN. Acclimatization of tissue cultured plants. Current Science 2003;85 17041712.

[39] Lavanya M Venkateshwarlu B, Devi BP. Acclimatization of neem microshoots adaptable to semi-sterile conditions. Indian Journal of Biotechnology 2009;8 218-222. 
[40] Premkumar A, Mercado JA, Quesada MA. Effects of in vitro tissue culture conditions and acclimatization on the contents of Rubisco, leaf soluble proteins, photosynthetic pigments and C/N ratio. Journal of Plant Physiology 2001;158 835-840. 